\title{
EFFECTS OF A PSYCHOLOGICAL SKILL TRAINING PROGRAM ON ANXIETY LEVELS IN TOP KARATE ATHLETES
}

\author{
EFEITOS DE UM PROGRAMA DE TREINO DE HABILIDADE PSICOLÓGICA SOBRE OS NIVIEIS DEANSIEDADE \\ EM ATLETAS DE CARATÊDEELITE
}

Original Article

ARTIGO ORIGINAL

Artículo Original

\author{
EFECTOS DE UN PROGRAMA DE ENTRENAMIENTO DE HABILIDAD PSICOLÓGICA SOBRE LOS NIVELES \\ DEANSIEDAD ENATLETAS DE KARATEDEÉLITE
}

\section{Ana Veskovićl \\ (Sport Psychologist) \\ Nenad Koropanovski² \\ (Physical Education Professor) \\ Milivoj Dopsaj ${ }^{3}$ \\ (Physical Education Professor) \\ Srećko Jovanovićc \\ (Physical Education Professor)}

1. University of Belgrade, Faculty of Sport and Physical Education, Serbia.

2. University of Criminal

Investigation and Police Studies, Specialized Physical Education,

Belgrade, Serbia.

3. South Ural State University, SUSU, University in Chelyabinsk, Russian Federation.

4. University "Union - Nikola Tesla",

Faculty of Sport, Belgrade, Serbia.

\section{Correspondence:}

Nenad Koropanovski

University of Criminal Investigation and Police Studies, Cara Dušana 196, 11080, Belgrade, Serbia. nenad. koropanovski@kpu.edu.rs

\begin{abstract}
Introduction: To achieve an improvement in self-regulation, and consequently competitive performance, it is necessary to evaluate psychological skills training programs. It was hypothesized that the introduction of autogenic training and guided imagery could bring about positive changes in anxiety and self-confidence, as compared to regular training and competitive activities. Objective: To investigate the effects of a psychological skills training program on the optimization of anxiety and self-confidence. Methods: Twenty-four athletes from the Serbian national karate team were divided into experimental (EXP) and control (CON) groups. During eight weeks, both groups underwent an identical karate training and competing program. The program was adapted for top karate athletes according to their daily routines and the specific demands of the activity. In addition, the EXP group underwent the psychological skills training program, based on autogenic training and guided imagery. The Competitive State Anxiety Inventory-2 was used to measure the multidimensional construct of the state of anxiety, and the Movement Imagery Questionnaire-3 to assess individual ability to imagine movements. Results: Repeated measures ANOVA results indicated a difference in anxiety levels between the EXP and CON groups after the intervention. Further analysis indicated a decrease in cognitive anxiety and an increase in self-confidence among participants from the EXP group. Conclusion: The applied psychological skills program had a positive effect on anxiety optimization and self-confidence levels in top karate athletes. As emotional self-regulation is also crucial for athletes of other sports, the implementation of this intervention can be recommended, provided that it is adapted to the specific characteristics of each sport. Level of evidence Il; Therapeutic studies - Investigating treatments results.
\end{abstract}

Keywords: Martial arts; Anxiety; Autogenic training.

\section{RESUMO}

Introdução: Para a melhoria da autorregulação e, consequentemente, do desempenho competitivo, faz-se necessário avaliar os programas de treino das habilidades psicológicas. Foi formulada a hipótese de que os treinos autogênico e de visualização guiada poderiam induzir alterações positivas na ansiedade e na autoconfiança, quando comparados à prática das atividades regulares de treino-competição. Objetivo: Investigar os efeitos de um programa de treino de habilidades psicológicas na otimização da ansiedade e da autoconfiança. Métodos: Foram divididos em Grupos Experimental (EXP) e Controle (CON) 24 atletas da equipe nacional de caratê da Sérvia. Ao longo de 8 semanas, ambos os grupos foram submetidos a um programa de treino e competição idêntico. $O$ programa foi adaptado para atletas de elite de caratê de acordo com suas rotinas diárias e as demandas específicas da modalidade. Adicionalmente, o grupo EXP participou do programa de treino de habilidades psicológicas, baseado no treino autogênico e na visualização guiada. Foram utilizados o Inventário de Estado de Ansiedade Competitiva-2, para medir o constructo multidimensional do estado de ansiedade, e o Questionário de Imagens de Movimento-3, para avaliar a habilidade individual para imaginar os movimentos. Resultados: Os resultados da ANOVA por medidas repetidas indicaram diferença nos níveis de ansiedade dos Grupos EXP e CON após a intervenção. Análise mais profunda indicou redução da ansiedade cognitiva e aumento da autoconfiança nos participantes do Grupo EXP. Conclusão: O programa habilidades mentais aplicado apresentou efeito positivo na otimização da ansiedade e dos níveis de autoconfiança dos caratecas de elite. Uma vez que a autorregulação do estado psicológico também é crucial para atletas de outras modalidades, a implementação desta intervenção pode ser recomendada, desde que adaptada às suas especificidades. Nivel de evidência ll; Estudos terapêticos investigação dos resultados do tratamento.

Descritores: Artes marciais; Ansiedade; Treinamento autógeno.

\section{RESUMEN}

Introducción: Para la mejora de la autorregulación y, consiguientemente, del desempeño competitivo, se hace necesario evaluar los programas de entrenamiento de las habilidades psicológicas. Fue formulada la hipótesis de que los entrenamientos autógeno y de visualización guiada podrían inducir alteraciones positivas en la ansiedady 
en la autoconfianza, cuando comparados a la práctica de las actividades regulares de entrenamiento-competición. Objetivo: Investigar los efectos de un programa de entrenamiento de habilidades psicológicas en la optimización de la ansiedad y de la autoconfianza. Métodos: Fueron divididos en Grupos Experimental (EXP) y Control (CON) 24 atletas del equipo nacional de karate de Serbia. A lo largo de 8 semanas, ambos grupos fueron sometidos a un programa de entrenamiento y competición idéntico. El programa fue adaptado para atletas de élite de karate de acuerdo con sus rutinas diarias y las demandas específicas de la modalidad. Adicionalmente, el grupo EXP participó en el programa de entrenamiento de habilidades psicológicas, basado en el entrenamiento autógeno y en la visualización guiada. Fueron utilizados el Inventario de Estado de Ansiedad Competitiva-2, para medir el constructo multidimensional del estado de ansiedad, y el Cuestionario de Imágenes de Movimiento-3, para evaluar la habilidad individual para imaginar los movimientos. Resultados: Los resultados de ANOVA por medidas repetidas indicaron diferencia en los niveles de ansiedad de los Grupos EXP y CON después de la intervención. Un análisis más profundo indicó reducción de la ansiedad cognitiva y aumento de la autoconfianza en los participantes del Grupo EXP. Conclusión: El programa de habilidades mentales aplicado presentó efecto positivo en la optimización de la ansiedad y de los niveles de autoconfianza de los karatecas de élite. Dado que la autorregulación del estado psicológico también es crucial para atletas de otras modalidades, puede ser recomendada la implementación de esta intervención, desde que sea adaptada a sus especificidades. Nivel de evidencia Il; Estudios terapéuticos investigación de los resultados del tratamiento.

Descriptores: Artes marciales; Ansiedad; Entrenamiento autogénico

\section{INTRODUCTION}

There is a clear connection between anxiety and sports performance. If the stressors and competition requirements surpass athletes' coping capacities, they will display an anxiety imbalance with their preferences and sports performance. ${ }^{2}$ For the relaxation techniques significant for the regulation of arousal levels to be efficient, it is important that they are adjusted to the athlete's characteristics, the context and the phase of the competition, specific sources of stress, sport requirements, and competing levels. They also need to be easy to administer and apply in real life situations. ${ }^{2-4}$ So far, relaxation techniques have not been adjusted well enough to the needs of athletes. ${ }^{5}$ In order to achieve successful modification of these techniques, the requirements and characteristics of competition in a specific sport should be considered.

In combat sports, two opponents face each other, ${ }^{6}$ and although the rules of refereeing are well defined, the competitors are affected by the opponent's actions, fearing defeat or injury. Due to the strict competition rules regulating the performance, the influence of referees' subjective views, and the possibility of injury, karate athletes require extreme concentration and a high level of mental resistance. Hence, there is a need for the application of special anxiety optimization techniques adjusted to the variable conditions of the sport activities, especially related to the stress generated during competitions. ${ }^{7}$ In previous research with karate athletes, it was concluded that the participants from the combined imagery and relaxation group had lower anxiety levels after the treatment. ${ }^{8}$

The objective of this research was the effectiveness of the specially adapted psychological skills training program for top karate athletes with respect to anxiety and self-confidence optimization. Since previous research ${ }^{9,10}$ has shown that the effects of the treatment increase as the ability for imagery rises, the imagery ability should be measured at baseline. ${ }^{11}$ It was hypothesized that specifically modified autogenic training (AAT) was less time-consuming than classical autogenic training (AT), and specifically constructed imagery intervention (IMI) would induce more positive changes to anxiety and self-confidence levels compared to regular training and competing activities.

\section{MATERIAL AND METHODS}

Twenty-four top karate athletes (age $22.83 \pm 3.51$ years, experience $14.58 \pm 3.90$ years, 15 men, 9 women) participated in this study. All participants were members of Serbian national karate team (WKF). The procedure was conducted according to the "Declaration of Helsinki for recommendations guiding physicians in biomedical research involving human subjects", and with the permission of the Ethics Committee of the Faculty of Sport and Physical Education in Belgrade (Project I|l47015, Protocol No. 484-2). All participants signed the Term of Free and Informed Consent.

The karate athletes were randomly distributed in two groups: experimental (EXP) and control (CON). For the purpose of this research, the Movement Imagery Questionnaire-3 (MIQ-3) and Competitive State Anxiety Inventory-2 (CSAI-2) were applied. MIQ-3 is composed of three subscales assessing the individual's ability to image four movements (knee lift, jump, arm movement, and waist bend) using internal visual imagery, external visual imagery and kinesthetic imagery adapted by Williams et al. ${ }^{12}$ Before issuing the questionnaire, the participants were given the definitions of external and internal visual imagery as well as kinesthetic imagery. Participants' responses were recorded on a 7-point Likert scale, of which the acceptable internal consistency had been previously established. ${ }^{13}$ CSAI-2 is one of the leading instruments measuring the multidimensional construct of state anxiety. ${ }^{14}$ The response scale required the participants to rate the intensity of each single symptom, with scores ranging from 9 to 36 for each subscale. Satisfactory internal consistency had been previously reported. . $^{14,15}$

The experimental procedure lasted for 8 weeks. $\mathrm{CON}(\mathrm{N}=12)$ and $\operatorname{EXP}(\mathrm{N}=12)$ had an identical training and competing program. Also, EXP practiced in a weekly group session with a psychologist, performing given instructions individually over the remaining six days.

Psychological skills training consisted of AAT and IMI. AAT was used to avoid the main limitation of classic AT, that is, the duration (3-10 months) necessary for athletes to become proficient in it.2, ${ }^{16,17}$ The IMI script, defined by a psychologist and a karate expert, was exclusively prepared for the needs of the top karate athletes. It is believed that top athletes who think that they have already "peaked" will benefit most from the training, to ensure their further commitment.

The main goal of AAT is to relax the body but to keep the mind active and alert, and it contains six basic exercises. Participants complete each of these in 1-2 minutes. During the learning process, the AAT exercises are performed 1-3 times per day. On the other hand, the script focused on the aspects of motivational general arousal (MGA) and motivational general mastery (MGM). Since imagery is a trainable skill, the IMI was modified 
in accordance with participants' progress. ${ }^{15}$ The script reading speed was adjusted twice during the treatment, after the fourth and the sixth sessions. The duration of a single script ranged from 90 to 120 seconds.

An experienced psychologist administered the intervention, following strict instructions in order to avoid the experimenter bias effect. During the sessions, the participants were given detailed exercise instructions, which they had to perform during the following week. The sessions were divided into two thematic parts. In the first part (15-25 minutes), the participants exchanged training experiences gained over the course of the previous week. In the second part (5-22 minutes), after being given detailed instructions for a new basic AAT exercise, the athletes were guided through the intervention. After the group session, each participant received an audio recording to use individually. Also, after each group session a new three-minute AAT exercise was added to the recording, followed by the script. The training for the newly introduced exercise in the actual week lasted two minutes, and one minute for the other exercises.

During the first week, the session started with a preparatory exercise. The purpose of this exercise was to focus the participant's attention on dominant distractors with the aim of gradual adaptation. During the second week, the implementation of the first AAT exercise started, where the participant's attention was focused on the dominant arm and the search for the sense of its weight. Although the sensation need not be intense, the participant was supposed to sense the weight of the dominant arm objectively. The sense of weight should be successfully found 5-6 times. Gradually, the sense of weight spread to the other limbs. The implementation principles for the other exercises were identical. From the third to the seventh week, each exercise was added in the following order: sensing warmth in the dominant arm, becoming aware of spontaneous breathing at rest, finding the heartbeat, and recognizing warmth in the abdomen and coolness at the forehead. During the eighth week, when all six basic exercises had been mastered, they were combined into the following pairs: weight-warmth, breathing-heartbeat, and abdomen-forehead, thus shortening the time of AAT performance and preserving the motivation and active attention of participants during exercise.

\section{Statistical analysis}

Means and standard deviations (Mean \pm SD) for all variables were calculated. The Cronbach's alpha coefficient was calculated for all relevant variables. T-tests for independent samples were applied to age, sport experience and all three dimensions of imagery differences among the two groups.

Two-way between-within ANOVA was applied to the results for somatic anxiety, cognitive anxiety and self-confidence to assess the differences between EXP and CON, and Pre-intervention and Post-intervention. Eta squared $\left(n^{2}\right)$ was calculated for the ANOVA where the values of the effect sizes of $0.01,0.06$ and above 0.14 were considered small, medium and large, respectively. ${ }^{18}$ The initial results revealed that none of the dependent variables deviated significantly from their normal distribution (Kolmogoro$v$-Smirnov test). The level of statistical significance was set at $p<0.05$. All statistical tests were performed using SPSS 20 (IBM, Armonk, NY).

\section{RESULTS}

Except for the cognitive anxiety scale in Pre-intervention, all other scales showed high Cronbach's alpha coefficients, indicating good internal consistency. (Table 1)

The descriptive data regarding age, sport experience and initial internal visual imagery, external visual imagery and kinesthetic imagery are shown in Table 2.

T-tests for independent samples showed no statistical differences between groups for all variables.

Figure 1 shows the average across the subject data of somatic anxiety, cognitive anxiety and self-confidence.
The somatic anxiety revealed a significant main effect of intervention $\left[F_{(1,22)}=15.179, \eta^{2}=0.16, p<0.01\right]$. However neither the main effect of group $\left[F_{(1,22)}=0.317, \eta^{2}=0.01, p=0.579\right]$, nor their interaction $\left[F_{(1,22)}=0.650, \eta^{2}=0.01, p=0.429\right]$ were significant. Both $\operatorname{EXP}(p<0.01)$ and CON $(p<0.05)$ had lower somatic anxiety in Post-intervention than in Pre-intervention. In addition, EXP had a higher numeric difference between

Table 1. Alpha coefficient for SCAI-2 and MIQ-3 for Pre- and Post-intervention.

\begin{tabular}{c|c|c|c|c|c|c}
\hline & $\begin{array}{c}\text { Somatic } \\
\text { anxiety }\end{array}$ & $\begin{array}{c}\text { Cognitive } \\
\text { anxiety }\end{array}$ & $\begin{array}{c}\text { Self- } \\
\text { confidence }\end{array}$ & IVI & EVI & KI \\
\hline Pre-intervention & 0.773 & 0.514 & 0.845 & 0.828 & 0.825 & 0.833 \\
\hline Post-intervention & 0.675 & 0.864 & 0.899 & $/$ & $/$ & $/$ \\
\hline
\end{tabular}

* $\mathrm{VI}=$ internal visual imagery, $\mathrm{EVI}=$ external visual imagery, and $\mathrm{KI}=$ kinesthetic imagery.

Table 2. Descriptive statistics for age, sport experience and MIQ-3 for EXP and CON.

\begin{tabular}{c|c|c}
\hline Variable & EXP & CON \\
\hline Age & $23.08 \pm 4.295$ & $22.58 \pm 2.678$ \\
\hline SE & $14.25 \pm 4.957$ & $14.92 \pm 2.644$ \\
\hline EVI & $5.925 \pm 1.202$ & $6.500 \pm 0.486$ \\
\hline IVI & $6.125 \pm 0.988$ & $6.575 \pm 0.472$ \\
\hline KI & $5.825 \pm 1.253$ & $6.425 \pm 0.602$ \\
\hline
\end{tabular}

*data were shown as Mean \pm Standard Deviation. SE = sport experience, EVI = external visual imagery, IVI = internal visual imagery and $\mathrm{Kl}=$ kinesthetic imagery

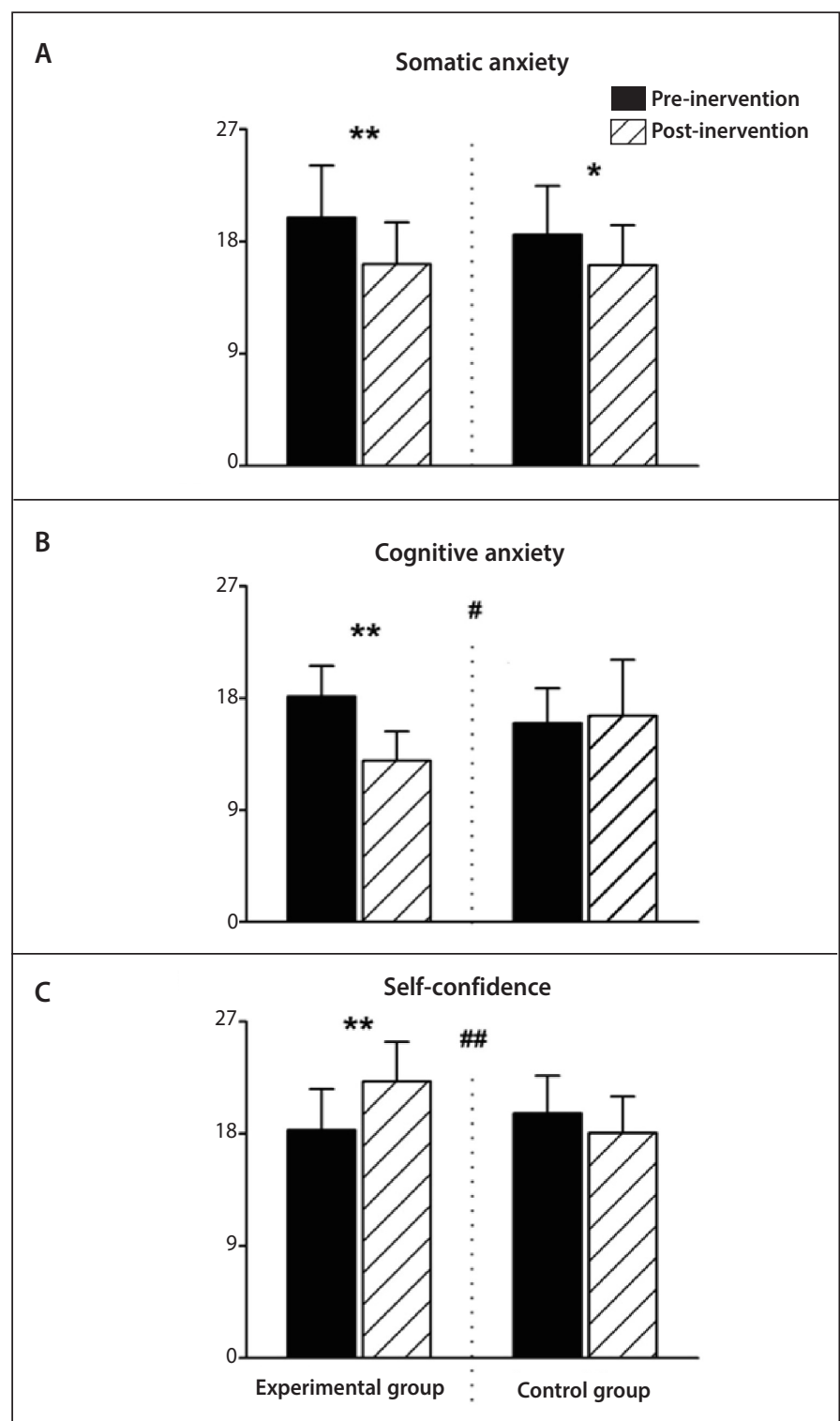

Figure 1. Pre- and Post-intervention (*) differences between EXP and CON (\#) in Somatic anxiety (A), Cognitive anxiety (B) and Self-confidence (C). 
interventions (3.74 scores; 18.79\%), that CON (2.46 scores; 13.25\%). In total, EXP decreased their somatic anxiety by 1.28 scores (5.54\%) more than CON.

Regarding cognitive anxiety, no significant main effect for the group $\left[F_{(1,22)}=0.583, \eta^{2}=0.01, p=0.453\right]$ was found, while the main effect of the intervention $\left[F_{(1,22)}=7.500, \eta^{2}=0.10, p=0.012\right]$ and their interaction was significant $\left[F_{(1,22)}=12.042, \eta^{2}=0.16, p<0.01\right]$. EXP had lower cognitive anxiety in Post-intervention than in Pre-intervention $(p<0.01)$. The same group also had a lower level of cognitive anxiety than CON in Post-intervention ( $p<0.05)$. Moreover, EXP had a higher numeric difference between the interventions (5.12 scores; 28.26\%), than CON (-0.60 scores; $-3.77 \%)$. In total, EXP decreased their cognitive anxiety by 5.72 scores (32.03\%) more than CON.

The self-confidence revealed no significant main effects for both groups $\left[F_{(1,22)}=1.613, \eta^{2}=0.04, p=0.217\right]$ and intervention $\left[F_{(1,22)}=\right.$ $\left.3.569, \eta^{2}=0.03, p=0.072\right]$. However, their interaction was significant $\left[F_{(1,22)}=19.547, \eta^{2}=0.16, p<0.01\right]$. EXP had a higher self-confidence in Post-intervention than in Pre-intervention $(p<0.01)$ and also had a higher self-confidence than CON in Post-intervention ( $p<0.01)$. Additionally, EXP had a higher numeric difference between the interventions (3.91 scores; $21.39 \%)$, that CON (-1.57 scores; -8.00\%). In total, EXP increased their self-confidence by 5.48 scores (29.38\%) more than CON.

\section{DISCUSSION}

In general, the obtained results showed that there was a significant improvement of various degrees in EXP, in all three separate dimensions of the anxiety response.

For somatic anxiety, there were two main observations. First, its intensity was significantly lower in both groups at Post-intervention, suggesting that the timing of the data collection relative to the competition phase affected the results. The initial measurement session was conducted at the early competition stage, while the final session took place immediately before the main competition. It is considered that situational antecedents of somatic anxiety mainly condition the response to stimuli. ${ }^{19}$ Therefore, our results suggested that before the final measurement, the athletes in both groups were more often exposed to conditioned stimuli, and the top athletes already possessed the ability to cope with and control anxiety. ${ }^{20}$ While earlier longitudinal research was aimed at the temporal nature of performers' anxiety responses at intervals prior to competition, ${ }_{1}^{21}$ and not at the fluctuation of anxiety during the competition season, our research focused on the latter. Secondly, our results showed that EXP progressed more than $\mathrm{CON}$, indicating that the effects of AAT and IMI were considerable in this anxiety component.

With respect to cognitive anxiety, its intensity after the intervention was considerably lower in EXP than in CON. Since this component is clearly related to uncertain expectation, perceived readiness is one of the most significant predictors of cognitive anxiety, as well as self-confidence. ${ }^{19}$ Thus, it is proposed that the joint effect of AAT, which focuses directly on relaxing the mind, 1 and MGA imagery, already identified as a predictor of cognitive state anxiety, ${ }^{22}$ which is directed to the regulation of emotions and activation levels, is one of the important factors for successful karate performance.

Finally, the most significant difference between Pre- and Post-intervention in EXP and between the two groups was attained in the self-confidence component. In this research, the MGM imagery was predominantly directed at the increase of self-confidence, specifically at confidently coping with and mastering challenging situations. Our results were compatible with the research on a sample of elite middle distance runners ${ }^{19}$ and high-level badminton players, ${ }^{23}$ indicating that MGM imagery represented a self-confidence facilitator. ${ }^{24}$ In practice, the imagery script was aimed at facilitating readiness for an adequate performance, which is one of the factors tied to the expectation of future success ${ }^{25}$ and also one of the most significant antecedents of selfconfidence development. ${ }^{19}$ Furthermore, this also could be an effect of AAT since the emotional arousal is one of the sources of self-confidence, and athletes are more likely to expect success when they are not tense and when they feel inner peace. ${ }^{1}$ An indirect confirmation of the greatest difference in this dimension after a cognitive intervention such as IMI has also been attained on a sample of elite junior tennis players. ${ }^{26}$

Mastering AAT skills up to the proficient level is not only more time-efficient than AT regarding the total duration of the treatment, but also concerning the daily athlete workload. Besides, the exercise performance itself is shorter compared to classical AT, which is especially important regarding the obligations and workload of top athletes. The application of AAT seems to be well adjusted to athletes, because it does not require special conditions, it is easy to administer and adjust to athletes' preferences and the conditions of performance. The athletes mastered all six basic AAT exercises as well as the application of AAT short form in a total of 8 weeks. The script was applied effectively to the needs of top karate athletes, with the basic aim of optimizing activation levels and the awareness of performance readiness, and the improvement of competition performance.

The research limitation to top athletes, especially in individual sports, lies in their small numbers. This research comprised the entire population of top karate athletes in Serbia and it was impossible to create a placebo group. It can be beneficial if future research observes the effects of the treatment on anxiety symptoms on a continuum from debilitative to facilitative, ${ }^{27}$ preferably over various time periods after ending the program. Also, researchers should specify separate contributions of AAT and imagery intervention, and include different competition disciplines and athletes'ages, as this will be of special interest to sport coaches.

\section{CONCLUSIONS}

A combination of AAT and IMI has an instrumental role in the improvement of the intensity levels of all three anxiety dimensions in top karate athletes. Since there are minor differences between top athletes, the cumulative effect of the intervention on already developed anxiety regulation could be of benefit for competition results. The value of this research could lie in the implementation of AAT+IMI as an integral part of top karate athletes' psychological preparation in the entire training and competition program. Finally, as self-regulation of psychological states is critical for all top athletes, the implementations of this treatment, adapted to the specifics of each sport, can be recommended.

\section{ACKNOWLEDGMENTS}

This paper is part of the project "Effects of applied physical activity on locomotor and metabolic, psycho-social and educational status of the population in Republic of Serbia" (No III47015), funded by the Ministry of Science and Technology Development of the Republic of Serbia (2011-2019).

All authors declare no potential conflict of interest related to this article

AUTHORS' CONTRIBUTIONS: Each author made significant individual contributions to this manuscript. AV (0000-0001-5260-5835)*: writing of the article, review, script, statistical processing and analysis, intellectual concept of the article and preparation of the entire research project; NK (0000-0002-7196-7185)*: script, data analysis and writing of the article; MD (0000-0001-7153-2993)*: responsible for all aspects of the study, and issues related to the integrity and accuracy of the study; SJ (0000-0002-4716-7428)*: substantial contribution to the interpretation of the study. *ORCID (Open Researcher and Contributor ID). 


\section{REFERENCES}

1. Weinberg RS, Gould D. Foundations of sport and exercise psychology. 6th ed. Illinois: Human Kinetics; 2015.

2. Hanton S, Thomas O, Mellalieu SD. Management of competitive stress in elite sport. In: Brewer BE, editor. Handbook of Sports Medicine and Science: sport Psychology. Wiley-Blackwell; 2009. p.30-42.

3. Park JK. Coping strategies used by Korean National athletes. Sport Psychol. 2000;14(1):63-80.

4. Holt NL, Hogg JM. Perceptions of stress and coping during preparations for the 1999 women's soccer World Cup finals. Sport Psychologist. 2002;16(3):251-71.

5. Elliott $D$, Polman $R$, Taylor J. The effects of relaxing music for anxiety control on competitive sport anxiety. Eur J Sport Sci. 2014;14(Suppl 1):S296-301.

6. Koropanovski N, Berjan B, Bozic RP, Pazin N, Sanader A, Jovanovic S, et al. Anthropometric and physical performance profiles of elite karate and kata competitors. J Hum Kinetics. 2011;30:107-14.

7. Sterkowicz S, Blecharz J, Sterkowicz-Przybycien K. Stress in sport situations experienced by people who practice karate. Arch Budo. 2012;8(2):65-77.

8. Weinberg RS, Seabourne TG, Jackson A. Effects of visuo-motor behavior rehearsal, relaxation, and imagery on karate performance. J Sport Exerc Psychol. 1981;3(3):228-38.

9. Cumming J, Ramsey R. Imagery interventions in sport. In: Mellalieu S, Hanton S. editors. Advances in applied sport psychology: a review. London; New York: Routledge and Taylor and Frances Group; 2009. p.5-36.

10. Cooley SJ, Williams SE, Burns VE, Cumming J. Methodological variations in guided imagery interventions using movement imagery scripts in sport: A systematic review. J Imag Res Sport Phys Activity. 2013;8(1):13-34.

11. Yahya MF, Ismail $M, A$ mer $A$. The idea of using practice in mind training program for rugby players to improve anxiety and kicking performance. Int J Sports Sci. 2016;6(2):70-5.

12. Williams SE, Cumming J, Edwards MG. The functional equivalence between movement imagery, observation, and execution influences imagery ability. Res Q Exerc Sport. 2011;82(3):555-64.

13. Williams SE, Cooley SJ, Cumming J. Layered stimulus response training improves motor imagery ability and movement execution. J Sport Exerc Psychol. 2013;35(1):60-71

14. Martens R, Vealey RS, Burton D. Competitive anxiety in sport. Champaign (IL): Human Kinetics; 1990
15. Martinent G, Ferrand C, Guillet E, Gautheur S. Validation of the French version of the Competitive State Anxiety Inventory-2 Revised (CSAl-2R) including frequency and direction scales. Psychol Sport Exerc. 2010;11(1):51-7

16. Krenz EW. Improving competitive performance with hypnotic suggestions and modified autogenic training: Case reports. Am J Clin Hypn. 1984;27(1):58-63.

17. Williams JM, Harris DV. Relaxation and energizing techniques for regulating of arousal. In: Williams JM editor. Applied sport psychology: Personal growth to peak performance. New York: Mayfield; 2010. p.247-61

18. Cohen J. Statistical power analysis for the behavioral sciences. 2nd ed. New Jersey: Lawrence Erlbaum Associates, Hillsdale; 1988

19. Jones JG, Swain A, Cale A. Antecedents of multidimensional competitive state anxiety and self-confidence in elite intercollegiate middle-distance runners. Sport Psychol. 1990;4(2):107-18.

20. Gould D, Dieffenbach K, Moffett A. Psychological characteristics and their development in Olympic champions. J Appl Sport Psychol. 2002;14(3):172-204.

21. Mellalieu SD, Hanton S, Fletcher D. Competitive anxiety review: Recent directions in sport psychology research. New York: Nova Science Publishers, Inc; 2009.

22. Vadoa EA, Hall CR, Moritz SE. The relationship between competitive anxiety and imagery use. J App Sport Psychol. 1997;9(2):241-53.

23. Callow $\mathrm{N}$, Hardy L, Hall C. The effects of a motivational general-mastery imagery intervention on the sport confidence of high-level badminton players. Res Q Exerc Sport. 2001;72(4):389-400.

24. Strachan L, Munroe-Chandler K. Using imagery to predict self-confidence and anxiety in young elite athletes. J Imag Res Sport Phys Activity. 2006;1 (1):1-19.

25. Gould D, Petlichkoff L, Weinberg RS. Antecedent of, temporal changes in, and relationships between CSAl-2 subcomponents. J Sport Exerc Psychol. 1984;6(3):289-304

26. Mamassis $\mathrm{G}$, Doganis $\mathrm{G}$. The effects of a mental training program on juniors pre-competitive anxiety, self-confidence, and tennis performance. J Appl Sport Psychol. 2004;16(2):118-37.

27. Fletcher $D$, Hanton S. The relationship between psychological skills usage and competitive anxiety responses. Psychol Sport Exerc. 2001;2(2):89-101. 